Acta Crystallographica Section E

Structure Reports

Online

ISSN 1600-5368

S. M. Malathy Sony, ${ }^{a}$ P. Charles, ${ }^{a}$ M. N. Ponnuswamy, ${ }^{a *}$ H. S. Yathirajan $^{b}$ and M. Nethaji

${ }^{a}$ Department of Crystallography and Biophysics, University of Madras, Guindy Campus, Chennai 600 025, India, ${ }^{b}$ Department of Studies in

Chemistry, University of Mysore,

Manasagangotri, Mysore 570 006, India, and

${ }^{\mathbf{c}}$ Department of Inorganic and Physical

Chemistry, Indian Institute of Science, Bangalore

560012 , India

Correspondence e-mail:

mnpsy2004@yahoo.com

\section{Key indicators}

Single-crystal X-ray study

$T=293 \mathrm{~K}$

Mean $\sigma(\mathrm{C}-\mathrm{C})=0.004 \AA$

$R$ factor $=0.064$

$w R$ factor $=0.184$

Data-to-parameter ratio $=17.0$

For details of how these key indicators were automatically derived from the article, see http://journals.iucr.org/e.
(C) 2005 International Union of Crystallography Printed in Great Britain - all rights reserved

\title{
4'-\{[2-(But-2-enyl)-4-chloro-5-formyl-1H-imidazol- 1-yl]methyl\}biphenyl-2-carbonitrile
}

In the title structure, $\mathrm{C}_{22} \mathrm{H}_{18} \mathrm{ClN}_{3} \mathrm{O}$, the dihedral angle between the benzene rings of the biphenyl system is $41.6(1)^{\circ}$; they are approximately perpendicular to the planar imidazole ring. The crystal structure is stabilized by $\mathrm{C}-$ $\mathrm{H} \cdots \mathrm{Cl}, \mathrm{C}-\mathrm{H} \cdots \mathrm{O}$ and $\mathrm{C}-\mathrm{H} \cdots \mathrm{N}$ hydrogen bonds and $\mathrm{C}-$ $\mathrm{H} \cdots \pi$ interactions.

\section{Comment}

Imidazole is a fundamental building block of many proteins and other biological systems. It also acts as a ligand that will bind readily to a metal ion in aqueous systems. Imidazole-4acetic acid is a catabolite of histamine and is present in the brain (Prell et al., 1996), and an imidazole succinic acid complex is an active non-steroidal aromatase inhibitor (Schiavo et al., 1988). The title compound, (I), serves as a key intermediate for the preparation of the antihypertensive drug losartan potassium (Griffiths et al., 1999).

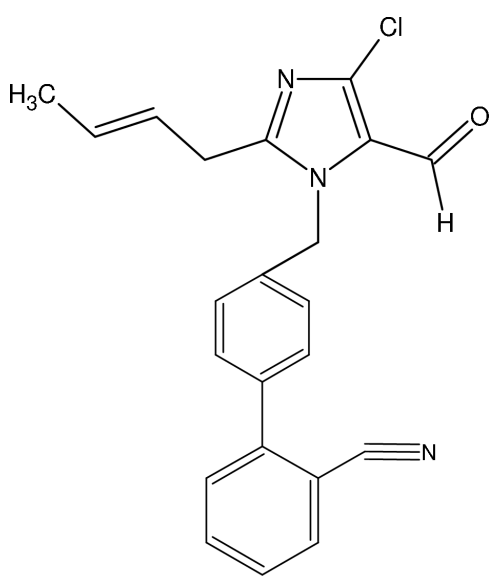

(I)

As expected, the cyanide group is linear, with angle $\mathrm{C} 14-$ C19-N20 equal to $176.9(3)^{\circ}$. Angles C9-C10-C11 of $117.6(2)^{\circ}$ and $\mathrm{C} 14-\mathrm{C} 13-\mathrm{C} 18$ of $117.1(2)^{\circ}$ are contracted, due to the steric hindrance of the biphenyl system. The but-2enyl chain is in an extended conformation, as noted from the torsion angles $\mathrm{N} 1-\mathrm{C} 2-\mathrm{C} 21-\mathrm{C} 22\left[156.2(3)^{\circ}\right], \mathrm{C} 2-\mathrm{C} 21-$ $\mathrm{C} 22-\mathrm{C} 23 \quad\left[-165.5(5)^{\circ}\right]$ and $\mathrm{C} 21-\mathrm{C} 22-\mathrm{C} 23-\mathrm{C} 24$ $\left[178.0(5)^{\circ}\right]$. The dihedral angle between the benzene rings of the biphenyl system is $41.6(1)^{\circ}$; rings $\mathrm{C} 7-\mathrm{C} 12$ and $\mathrm{C} 13-\mathrm{C} 18$ make angles of $73.3(1)$ and $85.9(1)^{\circ}$, respectively, with the plane of the imidazole ring.

The crystal structure of (I) is stabilized by $\mathrm{C}-\mathrm{H} \cdots \mathrm{Cl}, \mathrm{C}-$ $\mathrm{H} \cdots \mathrm{O}$ and $\mathrm{C}-\mathrm{H} \cdots \mathrm{N}$ hydrogen bonds and $\mathrm{C}-\mathrm{H} \cdots \pi$ interactions (Table 1 and Fig. 2). The two interactions $\mathrm{C}-\mathrm{H} \cdots \mathrm{Cl}$ and the $\mathrm{C}-\mathrm{H} \cdots \mathrm{N}$ involving atom $\mathrm{N} 3$ of the imidazole result
Received 22 November 2004 Accepted 26 November 2004 Online 4 December 2004 
in the formation of a two-dimensional network in the $b c$ plane. A $\mathrm{C}-\mathrm{H} \cdots \pi$ interaction exists between $\mathrm{C} 11$ and benzene ring C13-C18 at $(-x,-y, 1-z)$, the distance between $\mathrm{C} 11$ and the centroid of the ring being $3.983 \AA$.

\section{Experimental}

To a suspension of sodium methoxide $(0.03 \mathrm{~mol}, 1.62 \mathrm{~g})$ in dimethylformamide (DMF, $25 \mathrm{ml}$ ) was added a solution of 2-(but-2enyl)-4-chloro-5-formylimidazole $(0.03 \mathrm{~mol}, 5.655 \mathrm{~g})$ in DMF. The mixture was stirred at $298 \mathrm{~K}$ for $30 \mathrm{~min}$, and to this was added dropwise a solution of 4-bromomethyl-2'-cyanobiphenyl $(0.025 \mathrm{~mol}$, $6.80 \mathrm{~g})$ in DMF $(25 \mathrm{ml})$. The mixture was stirred at room temperature for $24 \mathrm{~h}$ and evaporated to a residue under vacuum. The residue was dissolved in ethyl acetate $(70 \mathrm{ml})$, washed with brine $(20 \mathrm{ml})$, then water $(50 \mathrm{ml})$, dried using $\mathrm{Na}_{2} \mathrm{SO}_{4}$ and evaporated to yield a crude product; this was purified by column chromatography using a mixture (7:2) of $n$-hexane and ethyl acetate as eluant to give the title product, which was recrystallized from $\mathrm{CCl}_{4}$.

\section{Crystal data \\ $\mathrm{C}_{22} \mathrm{H}_{18} \mathrm{ClN}_{3} \mathrm{O}$ \\ $M_{r}=375.84$ \\ Monoclinic, $P 2_{1} / c$ \\ $a=9.080(6) \AA$ \\ $b=22.782(15) \AA$ \\ $c=10.055(7) \AA$ \\ $\beta=109.476(10)^{\circ}$ \\ $V=1961(2) \AA^{3}$ \\ $Z=4$}

$$
\begin{aligned}
& D_{x}=1.273 \mathrm{Mg} \mathrm{m}^{-3} \\
& \text { Mo } K \alpha \text { radiation } \\
& \text { Cell parameters from } 20332 \\
& \quad \text { reflections } \\
& \theta=1.8-27.4^{\circ} \\
& \mu=0.21 \mathrm{~mm}^{-1} \\
& T=293(2) \mathrm{K} \\
& \text { Rectangular block, colourless } \\
& 0.30 \times 0.25 \times 0.22 \mathrm{~mm}
\end{aligned}
$$

\section{Data collection}

Bruker SMART CCD area-detector diffractometer

$\omega$ scans

Absorption correction: none

20332 measured reflections

4143 independent reflections

$$
\begin{aligned}
& 3164 \text { reflections with } I>2 \sigma(I) \\
& R_{\text {int }}=0.022 \\
& \theta_{\max }=27.4^{\circ} \\
& h=-11 \rightarrow 11 \\
& k=-29 \rightarrow 28 \\
& l=-12 \rightarrow 12
\end{aligned}
$$

\section{Refinement}

Refinement on $F^{2}$

$R\left[F^{2}>2 \sigma\left(F^{2}\right)\right]=0.064$

$w R\left(F^{2}\right)=0.184$

$S=1.05$

4143 reflections

244 parameters

$\mathrm{H}$-atom parameters constrained

$$
\begin{gathered}
w=1 /\left[\sigma^{2}\left(F_{o}{ }^{2}\right)+(0.0786 P)^{2}\right. \\
+1.127 P] \\
\text { where } P=\left(F_{o}^{2}+2 F_{c}^{2}\right) / 3 \\
(\Delta / \sigma)_{\max }=0.083 \\
\Delta \rho_{\max }=0.64 \mathrm{e}^{-3} \\
\Delta \rho_{\min }=-0.36 \AA^{-3}
\end{gathered}
$$

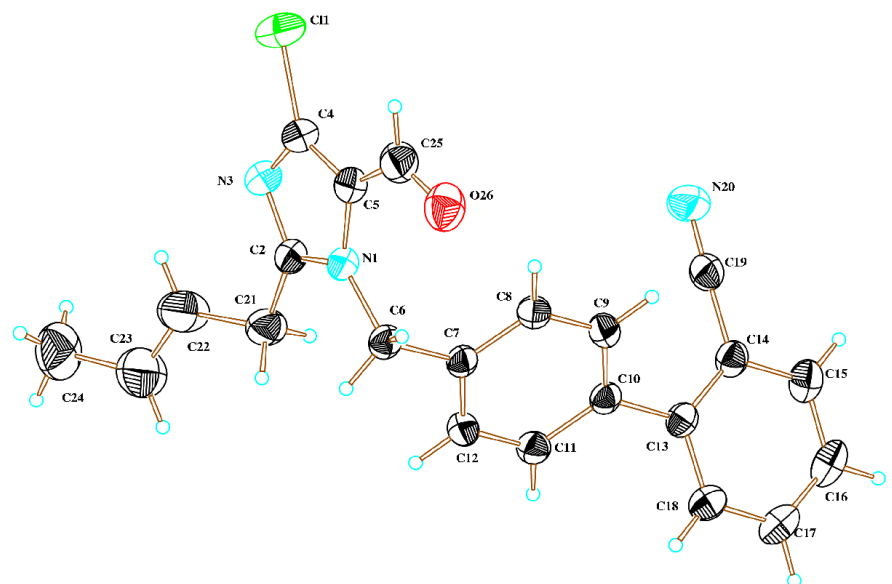

Figure 1

ZORTEP (Zsolnai, 1998) plot of the title molecule, showing the atomic numbering scheme. Displacement ellipsoids are drawn at the $30 \%$ probability level.

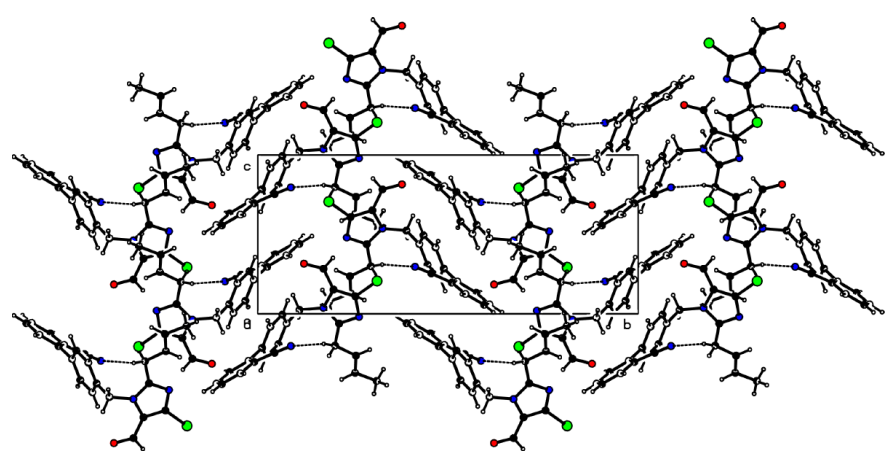

Figure 2

A packing diagram of the crystal structure, viewed down the $a$ axis. Dashed lines represent hydrogen bonds.

Data collection: SMART (Siemens, 1996); cell refinement: SAINT (Siemens, 1996); data reduction: SAINT; program(s) used to solve structure: SHELXS97 (Sheldrick, 1997); program(s) used to refine structure: SHELXL97 (Sheldrick, 1997); molecular graphics: PLATON (Spek, 2003), ORTEP-3 (Farrugia, 1997) and ZORTEP (Zsolnai, 1998); software used to prepare material for publication: PLATON.

SMMS acknowledges the Council of Scientific and Industrial Research for financial support.

\section{References}

Farrugia, L. J. (1997). J. Appl. Cryst. 30, 565.

Griffiths, G. J., Hauck, M. B., Imwinkelried, R., Kohr, J., Roten, C. A. \& Stucky, G. C. (1999). J. Org. Chem. 64, 8084-8086.

Prell, G. D., Douyon, E., Sawyer, W. \& Morrishow, A. M. (1996). J. Neurochem. 66, 2153-2155.

Schiavo, D. M., Green, J. D., Triana, V. M., Spaet, R. \& Zaidi, I. (1988). Fundam. Appl. Toxicol. 10, 329-331.

Sheldrick, G. M. (1997). SHELXS97 and SHELXL97. University of Göttingen, Germany.

Siemens (1996). SAINT (Version 4) and SMART. Siemens Analytical X-ray Instruments Inc., Madison, Wisconsin, USA.

Spek, A. L. (2003). J. Appl. Cryst. 36, 7-13.

Zsolnai, L. (1998). ZORTEP. University of Heidelberg, Germany. 